\title{
Co-occurrence of three types of egg policing in the Norwegian wasp Dolichovespula norwegica
}

\author{
Wim Bonckaert • Adam Tofilski • Fabio S. Nascimento • \\ Johan Billen • Francis L. W. Ratnieks • Tom Wenseleers
}

Received: 10 May 2010 /Revised: 1 September 2010 / Accepted: 11 September 2010

(C) Springer-Verlag 2010

\begin{abstract}
In insect societies, workers often try to challenge the reproductive monopoly of the queen by laying their own eggs. Successful worker reproduction, however, is frequently prevented by queen policing or worker policing, whereby either the mother queen or non-reproductive workers selectively kill worker-laid eggs. Recently, a third mechanism- -"selfish" worker policing-has also been described in which the workers selectively police workerlaid eggs but also lay eggs themselves. Here, we present results from the monogynous wasp Dolichovespula norwegica, which show that all three kinds of policing - queen policing, worker policing and "selfish" worker policing - co-occur. The net effect of these three kinds of policing collectively favoured
\end{abstract}

Communicated by R. Moritz

Electronic supplementary material The online version of this article (doi:10.1007/s00265-010-1064-3) contains supplementary material, which is available to authorized users.

W. Bonckaert $(\square) \cdot J$. Billen $\cdot$ T. Wenseleers

Zoological Institute, Catholic University of Leuven,

Leuven, Belgium

e-mail: wim.bonckaert@bio.kuleuven.be

A. Tofilski

Department of Pomology and Apiculture, Agricultural University,

Krakow, Poland

F. S. Nascimento

Departamento de Biologia,

FFCLRP - Universidade de São Paulo,

Av. Bandeirantes, 3900,

14040-901 Ribeirão Preto - SP, Brasil

F. L. W. Ratnieks

Laboratory of Apiculture and Social Insects,

Department of Biological and Environmental Science,

University of Sussex,

Brighton BN1 9QG, UK the queen's reproduction, as within 1 day $44 \%$ of the workerlaid eggs versus only $8 \%$ of the queen-laid eggs were eaten. Of the worker-laid eggs that were killed by workers, approximately two thirds were eaten by the reproductive workers even though these made up only a small proportion, $8 \%$, of the work force. This means that policing workers obtained both direct fitness benefits as well as indirect (inclusive) fitness. In addition, we show that worker policing was carried out by a limited, specialised set of workers that was estimated to constitute approximately one quarter of the whole colony and of which $66 \%$ were non-reproductive.

Keywords Reproductive conflict · Vespinae wasps · Worker reproduction - Selfish worker policing · Queen policing .

Worker policing

\section{Introduction}

Social insects are well known for their cooperation, but the non-clonal structure of their colonies also leads to genetic conflicts among society members (Ratnieks and Reeve 1992; Bourke and Franks 1995; Queller and Strassmann 1998; Queller 2000; Bourke 2005; Ratnieks et al. 2006). One of these conflicts is over male production. Workers, although normally unable to mate, possess functional ovaries and are therefore capable of laying unfertilised, male eggs. The workers and the queen, therefore, compete over male production (Trivers and Hare 1976; Bourke 1988; Hammond and Keller 2004; Ratnieks et al. 2006; Wenseleers and Ratnieks 2006a). One important mechanism that can resolve this conflict is policing, whereby workers are prevented from successfully reproducing, thereby maintaining the reproductive primacy of the queen (Starr 1984; Ratnieks 1988; reviewed in Wenseleers and 
Ratnieks 2006a). Policing can be carried out both by the mother queen and by the workers, via either aggression or selective egg cannibalism (reviewed in Wenseleers and Ratnieks 2006a).

The occurrence of both queen and worker policing can be understood via kin selection theory (Hamilton 1964). On relatedness grounds, the queen is always selected to police worker reproduction because she is more related to her own sons $(r=1 / 2)$ than to the sons of the workers (grandsons, $r=$ 1/4) (Trivers and Hare 1976). On the other hand, queen policing has been primarily found in species with relatively small colonies and low effective paternity, such as the halictid bee Lasioglossum zephyrum (Michener and Brothers 1974), the bumblebee Bombus terrestris (Velthuis et al. 2002), the yellowjacket Vespula rufa (Wenseleers et al. 2005b) and the ant Dinoponera quadriceps (Monnin and Peeters 1997), where the queen can effectively monitor and control all colony members (Ratnieks and Reeve 1992; Bourke 1999). The workers, in turn, are selected to inhibit each other from reproducing particularly when they are more closely related to the queen's sons than to other workers' sons. This occurs when the effective queen mating frequency is greater than two (Starr 1984; Ratnieks 1988) or when colonies are headed by several single-mated but closely related mother queens (Crozier and Pamilo 1996). Worker policing, however, can also be selected for in the absence of relatedness benefits if it helps to increase colony productivity (e.g. by causing workers to work rather than reproduce, by preventing males being produced in an untimely manner or if it helps to eliminate eggs of low viability, Ratnieks 1988; Hartmann et al. 2003; Pirk et al. 2004; Nonacs 2006; Ohtsuki and Tsuji 2009) or if the removal of worker-laid eggs, which are all male, results in a more female-biased colony sex ratio (the workers' optimum, Foster and Ratnieks 2001b). In line with these predictions, worker policing has been found not only in all species so far investigated with effective queen mating frequencies greater than two, such as Apis honeybees (Apis mellifera, Apis florea and Apis cerana, Ratnieks and Visscher 1989; Halling et al. 2001; Oldroyd et al. 2001), the German wasp Vespula germanica (Bonckaert et al. 2008) and the ponerine ant Pachycondyla inversa (D'Ettorre et al. 2004; Kellner et al. 2007), but also in some species with single-mated queens, such as the hornet Vespa crabro (Foster et al. 2002) and the ant Camponotus floridanus (Endler et al. 2004).

Recently, a third form of policing - "selfish" worker policing - has been described in which workers selectively prevent other workers from reproducing but also occasionally lay eggs themselves (Wenseleers et al. 2005a; Ratnieks et al. 2006; Stroeymeyt et al. 2007; Brunner and Heinze 2009). Selfish worker policing is distinct from mere reproductive competition because it is discriminatory, as it is targeted at the killing of worker-laid eggs or aggression towards workers with a high reproductive potential (Stroeymeyt et al. 2007; Brunner and Heinze 2009) and thus causes a net increase in the queen's share of the reproduction. Selfish worker policing is selected because workers are always more closely related to own sons than to other workers' sons and hence represents a powerful kin-selected mechanism that may facilitate evolution of worker policing even in species where the workers are more closely related to sons of other workers than to sons of the queen. Nevertheless, detailed information on the distribution of selfish worker policing within the social Hymenoptera is currently lacking and has so far only been found in two paper wasps (Polistes chinensis antennalis and P. dominulus, Saigo and Tsuchida 2004; Liebig et al. 2005) and in the ant Temnothorax unifasciatus (Stroeymeyt et al. 2007; Brunner and Heinze 2009).

The aim of this study was to determine if selfish worker policing also occurs in the Norwegian wasp Dolichovespula norwegica, a member of the Vespinae wasps, which is a taxon that has been of great use in the study of queen and worker policing due to the wide variation in both colony size and queen mating frequency among species within this subfamily (Foster and Ratnieks 2001a; Wenseleers et al. 2005b; Wenseleers and Ratnieks 2006a; Hughes et al. 2008). Previously, worker policing has been found in several Dolichovespula species (Foster and Ratnieks 2000; Wenseleers et al. 2005a) even though effective queen mating frequencies were well below two. Nevertheless, the possibility of worker policing being partly driven by direct reproductive benefits, that is by "selfish" motives, has not yet been thoroughly investigated. This is because the majority of the policing studies in Vespinae wasps were done using colonies in which workers were not individually marked (e.g. Foster and Ratnieks 2001a; Foster et al. 2002; Wenseleers et al. 2005b; Bonckaert et al. 2008). As a result, it was not possible to verify whether policing was carried out exclusively by non-reproductive workers or also by egg-laying workers. A second aim of our study was to determine whether there was any specialisation among the workers in carrying out policing tasks. Although division of labour in social Hymenoptera is well known (Wilson 1971; Oster and Wilson 1978; Robinson 1992), it has rarely been looked for in the context of worker policing, and specialisation in policing behaviour has so far only been documented in the ant Pachycondyla inversa (van Zweden et al. 2007).

\section{Methods}

Study organism

In May and June 2004, 10 nests of the Norwegian wasp Dolichovespula norwegica were collected at Stanton Moor 
in the Peak District near Sheffield (UK). All nests were found low above the ground, nesting in bilberry (Vaccinium myrtillus) or ling heather (Calluna vulgaris) bushes. Of these, four contained a healthy-looking, actively egg-laying mother queen and were in the right stage, i.e. about to produce new sexuals, and were used for further observation (Table 1). Our study colonies contained 41-69 workers (Table 1), and observations were carried out at the end of June or the beginning of July, when colonies naturally rear young queens and males.

\section{Observation of egg laying and policing}

The four queenright study nests were transferred to $15 \mathrm{~cm}$ (width) $\times 17 \mathrm{~cm}($ depth $) \times 40 \mathrm{~cm}$ (height) wooden observation boxes maintained outside the Laboratory of Apiculture and Social Insects at the University of Sheffield. Workers were allowed to fly freely and forage naturally. All workers present when the nest was collected, plus any workers that emerged subsequently, were individually marked using numbered bee tags (Opalithplättchen) glued to the notum. All four nests successfully re-established and were used for observation following the protocol of Wenseleers et al. (2005a). Briefly, we removed the lower sexual comb of the nest, glued it on a piece of wire and removed all eggs, larvae and pupae so that all cells were available for egg laying. Subsequently, the comb was put back into its original position and held in place with modelling clay. We observed egg-laying and policing behaviour for $24 \mathrm{~h}$ per trial using small infrared night vision cameras (model MS37S, Maplin Electronics, Barnsley, UK) placed at the bottom of each observation box and connected to a computer using an AVerMedia EZmaker frame grabber (Avermedia, Milpitas, CA) and VirtualDub software, http:// www.virtualdub.org/. We inspected the comb by eye approximately every $4 \mathrm{~h}$ to confirm the appearance of new eggs and the absence of previously laid eggs. The positions of all eggs in the cells were recorded onto a map of the comb which allowed us to determine cases in which an egg had been replaced by a new egg, laid in another position inside the focal cell. A final inspection was made after $24 \mathrm{~h}$ to allow egg fate to be followed for up to 1 day. All video recordings were then analysed in detail to determine who laid the eggs and who policed them. This whole procedure was replicated six times for colony 20 and three times for colony 36 (Table 1). In colonies 21 and 24, only a single trial was made since the queen died after our first observation. Hence, the total observation time was $264(11 \times 24) \mathrm{h}$. Data from trials carried out on consecutive days were pooled; data from colony 20 , from two sets of trials carried out in June and July, were analysed separately (Table 1).

Egg laying is detectable by the insertion of the abdomen into a cell for several minutes (Wenseleers et al. 2005a). Egg eating is also clearly observable by the prolonged deep insertion of the head in a cell, followed by rotating or upward and downward movements (Wenseleers et al. 2005a). The comb inspections, combined with the recordings, confirmed the correct interpretation of all egg-eating events seen on video.

\section{Statistical analysis of observational data}

The survival of queen-laid and worker-laid eggs was compared using survival analysis methods (the KaplanMeier product-limit method and Gehan's Wilcoxon test, Lee and Wang 2003). Fisher's exact tests were used to determine if the queen, reproductive workers or nonreproductive workers selectively removed worker-laid eggs. This was done by comparing the number of eggs policed by individuals of a certain class with the number of queen-laid and worker-laid eggs that remained at the end of our trials in a two-by-two table (Table 2).

To determine if policing was carried out by a restricted number of workers and hence specialisation was present,

Table 1 Number of observation trials and start of these observations, colony size (number of workers), absolute and effective queen mating frequency, sister-sister relatedness and worker reproduction in the four Dolichovespula norwegica study colonies

\begin{tabular}{lcllllll}
\hline Colony & $\begin{array}{l}\text { Number of } \\
\text { observation } \\
\text { trials (h) }\end{array}$ & $\begin{array}{l}\text { Start of } \\
\text { observation series }\end{array}$ & $\begin{array}{l}\text { Colony } \\
\text { size }\end{array}$ & $\begin{array}{l}\text { Queen } \\
\text { mating } \\
\text { frequency }\end{array}$ & $\begin{array}{l}\text { Effective } \\
\text { queen mating } \\
\text { frequency }\end{array}$ & $\begin{array}{l}\text { Pedigree } \\
\text { sister-sister } \\
\text { relatedness }\end{array}$ & $\begin{array}{l}\text { \% of eggs laid by workers } \\
\text { total \# of eggs laid by } \\
\text { queen and workers) }\end{array}$ \\
\hline $20 \mathrm{~A}$ & $2(48)$ & 25 June 2004 & 55 & 1 & 1.00 & 0.75 & $15 \%(48)$ \\
$20 \mathrm{~B}$ & $4(96)$ & 13 July 2004 & 41 & & & $38 \%(119)$ \\
21 & $1(24)$ & 25 June 2004 & 53 & 2 & 1.22 & 0.66 & $19 \%(37)$ \\
24 & $1(24)$ & 29 June 2004 & 45 & 2 & 1.98 & 0.50 & $33 \%(72)$ \\
36 & $3(72)$ & 13 July 2004 & 69 & 1 & 1.00 & 0.75 & $13 \%(149)$ \\
Average & & & 53 & $1.50^{\mathrm{a}}$ & $1.20^{\mathrm{b}}$ & $0.67^{\mathrm{a}}$ & $24 \%(425)$ \\
\hline
\end{tabular}

\footnotetext{
${ }^{\mathrm{a}}$ Arithmetic mean
}

${ }^{\mathrm{b}}$ Harmonic mean 
Table 2 Survival of queen-laid and worker-laid eggs in four natural D. norwegica colonies

\begin{tabular}{|c|c|c|c|c|c|c|c|c|c|}
\hline \multirow[t]{2}{*}{ Colony } & \multirow[t]{2}{*}{ Egg type } & \multirow{2}{*}{$\begin{array}{c}\text { \# of eggs } \\
\text { laid during } \\
24 \mathrm{~h} \text { trial(s) }\end{array}$} & \multirow{2}{*}{$\begin{array}{l}\# \text { of eggs } \\
\text { policed }(\%)\end{array}$} & \multicolumn{5}{|c|}{ \# eggs policed by ( $\%$ of policed eggs) } & \multirow{2}{*}{$\begin{array}{l}\% \text { of eggs } \\
\text { removed by } \\
\text { he queen }\end{array}$} \\
\hline & & & & $\mathrm{Q}$ & NW & RW & $\mathrm{W} ?^{\mathrm{a}}$ & $?^{\mathrm{b}}$ & \\
\hline \multirow[t]{2}{*}{$20 \mathrm{~A}^{\mathrm{c}}$} & Queen-laid & 41 & $13(32 \%)$ & $0(0 \%)$ & $6(46 \%)$ & $3(23 \%)$ & $2(15 \%)$ & $2(15 \%)$ & \\
\hline & Worker-laid & 7 & $6(86 \%)$ & $3(50 \%)$ & $1(17 \%)$ & $2(33 \%)$ & $0(0 \%)$ & $0(0 \%)$ & $50 \%$ \\
\hline \multirow[t]{2}{*}{ 20B } & Queen-laid & 74 & $12(16 \%)$ & $0(0 \%)$ & $1(8 \%)$ & $1(8 \%)$ & $2(17 \%)$ & $8(67 \%)$ & \\
\hline & Worker-laid & 45 & $20(44 \%)$ & $4(20 \%)$ & $2(10 \%)$ & $7(35 \%)$ & $5(25 \%)$ & $2(10 \%)$ & $22 \%$ \\
\hline \multirow[t]{2}{*}{21} & Queen-laid & 30 & $1(33 \%)$ & $0(0 \%)$ & $1(100 \%)$ & $0(0 \%)$ & $0(0 \%)$ & $0(0 \%)$ & \\
\hline & Worker-laid & 7 & $7(100 \%)$ & $0(0 \%)$ & $2(29 \%)$ & $1(14 \%)$ & $2(29 \%)$ & $2(29 \%)$ & $0 \%$ \\
\hline \multirow[t]{2}{*}{24} & Queen-laid & 48 & $0(0 \%)$ & $0(0 \%)$ & $0(0 \%)$ & $0(0 \%)$ & $0(0 \%)$ & $0(0 \%)$ & \\
\hline & Worker-laid & 24 & $7(29 \%)$ & $5(71 \%)$ & $0(0 \%)$ & $1(14 \%)$ & $0(0 \%)$ & $1(14 \%)$ & $83 \%$ \\
\hline \multirow[t]{2}{*}{$36^{\mathrm{d}}$} & Queen-laid & 130 & $11(8 \%)$ & $0(0 \%)$ & $1(9 \%)$ & $3(27 \%)$ & $2(18 \%)$ & $5(45 \%)$ & \\
\hline & Worker-laid & 19 & $7(37 \%)$ & $1(14 \%)$ & $3(43 \%)$ & $2(29 \%)$ & $0(0 \%)$ & $1(14 \%)$ & $17 \%$ \\
\hline \multicolumn{10}{|c|}{ Total/average } \\
\hline \multicolumn{2}{|c|}{ Queen-laid eggs } & 323 & $37(11 \%)$ & $0(0 \%)$ & $9(24 \%)$ & $7(19 \%)$ & $6(16 \%)$ & $15(41 \%)$ & $0 \%$ \\
\hline \multicolumn{2}{|c|}{ Worker-laid eggs } & 102 & $47(46 \%)$ & $13(13 \%)$ & $8(17 \%)$ & $13(28 \%)$ & $7(15 \%)$ & $6(13 \%)$ & $32 \%$ \\
\hline \multicolumn{4}{|c|}{ Selectivity egg eating (one-sided Fisher exact test) } & $p=1.8 \times 10^{-10}$ & $p=0.003$ & $p=3.2 \times 10^{-6}$ & & $p=0.08$ & \\
\hline
\end{tabular}

$Q$ queen, $N W$ non-reproductive worker, $R W$ reproductive worker, $W$ ? unmarked worker, ? individual's identity (queen or worker) could not be determined

${ }^{a}$ Worker was not individually marked, so its reproductive status was unknown

${ }^{\mathrm{b}}$ Identity of the policing individual could not be determined due to the peripheral cells being obscured by nest envelope

${ }^{\mathrm{c}}$ Data from six 24-h trials pooled

${ }^{\mathrm{d}}$ Data from three 24-h trials pooled

we used a Kolmogorov-Smirnov test to test whether the number of eggs eaten by individual workers significantly deviated from a random (Poisson) distribution. The estimated true number of workers that policed in each colony $n_{\mathrm{p}}$, correcting for non-sampling, was estimated by fitting the distribution of the number of eggs eaten by each worker to one expected if egg eating was randomly (i.e. Poisson) distributed over a certain number of workers $n_{\mathrm{p}}$ and with the remainder of the workers not carrying out any policing. This best-fit value for $n_{\mathrm{p}}$ was determined using a maximum-likelihood procedure (the Mathematica code is available as electronic supplementary material).

Genetic analysis of queen mating frequency

To determine queen mating frequency and worker-worker relatedness, we genotyped 20 female larvae from each colony at three microsatellite loci, Rufa05 (Thorén et al. 1995), Rufal3 (Thorén et al. 1995) and List2019 (Daly et al. 2002), following the protocol used by Wenseleers et al. (2005b). Genotypes of the mother queens, determined by direct genotyping, were used to determine the number of males the queen has mated to (paternity) and to assign individual workers to particular patrilines using the Colony2 programme (Wang 2004; Wang and Santure 2009).
Individual patriline assignments were then used to calculate the effective queen mating frequency of each colony (Starr 1984), $M_{e}=1 / \sum p_{i}^{2}$, where $p_{i}$ is the proportional contri-

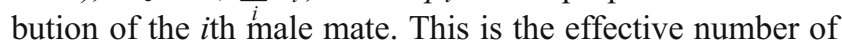
males the queen mated with, taking into account unequal paternity contribution. The corresponding pedigree workerworker relatedness was calculated for each colony as $r=$ $1 / 4+1 / 2 M_{e}$ (Pamilo 1991). Arithmetic mean relatedness and the corresponding harmonic mean paternity were calculated as population summary values. The harmonic mean is used because relatedness and paternity are inversely related (Boomsma and Ratnieks 1996).

Two types of errors potentially confound effective paternity estimates: non-detection and non-sampling (Boomsma and Ratnieks 1996). The non-detection error is the probability that father males have identical multilocus genotypes and hence cannot be distinguished; nonsampling error is the probability that one or more of the patrilines present are not sampled (Foster and Ratnieks 2001c; Nielsen et al. 2003). With 20 female larvae per colony being genotyped, the mean non-sampling probabilities of males with $33 \%$ or $10 \%$ paternity were 0.0003 and 0.12 , respectively. For males with very low paternity contributions, the non-sampling probability was significant. Nevertheless, such rare patrilines would only have a very 
small effect on the overall effective mating frequency estimate (Boomsma and Ratnieks 1996).

\section{Results}

Effective queen mating frequency and relatedness among workers

Genetic variation at the three microsatellite loci studied was moderate, with six, six and two detected alleles and expected heterozygosities of $0.79,0.77$ and 0.48 at loci Rufa05, Rufa13 and List2019, respectively. The arithmetic average queen mating frequency was 1.5 , with two of the study colonies (20 and 36 ) having a single-mated queen and the other two (21 and 24) having a double-mated queen (Table 1). This result is robust, given that the nondetection error was very low, 0.03 . The mean effective queen mating frequency, taking into account unequal paternity contributions, was 1.20 , resulting in an average worker-worker pedigree relatedness of 0.67 (Table 1). Hence, workers in our study colonies were more highly related to other workers' sons (by 0.34) than to the queen's sons (by 0.25 ) (single sample $t$ test, $t_{3}=2.80$, onesided $p=0.034)$. Our genetic methods were based on established procedures. Rufa05 and Rufal3 were developed for the red wasp Vespula rufa (Thorén et al. 1995) and have previously been successfully used in a genetic study of the colony kin structure of Dolichovespula norwegica colonies from the same population that we studied (Foster et al. 2001). Based on the genotyping of 206 males from eight colonies, no evidence for null alleles was found (K.R. Foster, personal communication; null alleles in social Hymenoptera would result in failed amplifications when haploid males are genotyped). List 2019 was originally developed for the common wasp Vespula vulgaris (Daly et al. 2002). As this locus had low polymorphism, with only two alleles found, it was not used for paternity assignments so that any null alleles would not have influenced our paternity estimates, even if they had been present.

Worker reproduction and selectivity of egg eating

Observational data show that worker reproduction occurred in all study colonies, with $24 \%$ of all eggs being workerlaid on average (range 13-38\%) (Table 1). Nevertheless, a large fraction of the worker-laid eggs were policed by other colony members, resulting in only $56 \%$ surviving for up to $24 \mathrm{~h}$ after first being laid versus $92 \%$ for the queen-laid eggs (Fig. 1). This difference in survival was highly significant (Kaplan-Meier survival analyses, Gehan's Wilcoxon test, test statistic $=8.07, p<0.00001$ ).

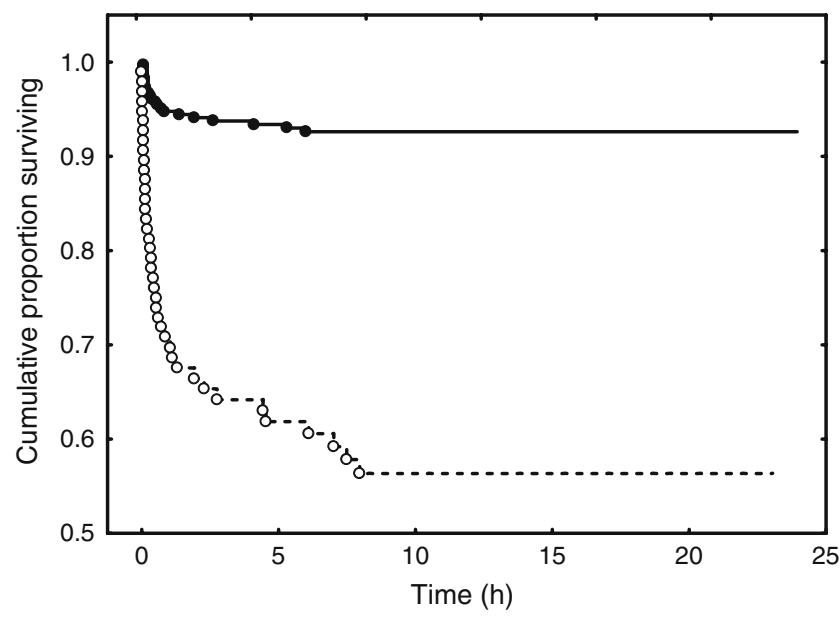

Fig. 1 Survival of queen-laid $(n=323)$ and worker-laid eggs $(n=102)$ in queenright Dolichovespula norwegica colonies as a function of the time after which they were first laid (Kaplan-Meier analysis). Data are pooled across a total of 1124 -h trials performed using four colonies. The solid and dotted lines represent the survival curves for queen-laid and worker-laid eggs, respectively. For clarity, only complete observations (eggs that were eaten) are shown

Identity of policing individuals

Individual marking of all colony members enabled us to determine the identity of most of the individuals that removed worker-laid eggs (Table 2, Fig. 2). These results show that $32 \%(13 / 41)$ of the policing of worker-laid eggs was carried out by the queen and $68 \%(28 / 41)$ by the workers (Table 2$)$. Interestingly, however, most $(62 \%, 13 / 21)$ of the eggs eaten by individually marked workers were removed by the few workers in each colony who themselves laid eggs (Table 2). When a worker-laid egg was eaten by a reproductive worker, it was replaced by an egg laid by the same reproductive worker in $31 \%$ of the cases $(4 / 13)$, by another egg-laying worker in $8 \%(1 / 13)$ and by the queen in the other $31 \%(4 / 13)$ of the cases. In the remaining four cases, the egg was not replaced within a trial. Furthermore, in $80 \%(8 / 10)$ of the cases in which we could unambiguously determine which worker laid an egg and which worker ate that same egg, a worker never ate her own egg. When a worker-laid egg was removed by a non-reproductive worker, it was replaced by a queen-laid egg in $25 \%$ (2/8) of the cases and by a worker-laid egg in 38\% $(3 / 8)$ of the cases. The queen was never seen to remove her own eggs. Workers did not always lay an egg in a cell after having eaten a queen-laid egg. When the queen-laid egg was removed by a reproductive worker, it was equally likely to be later replaced by the reproductive worker who ate the egg as by the queen herself (two out of four cases each). When a queen-laid egg was eaten by a non-reproductive worker and later replaced, it was always the queen who was the first to lay an egg in the cell (five out of five cases). The proportions of queen-laid eggs eaten by reproductive and non-reproductive workers were not significantly different (7/37 vs. 9/37, Fisher 

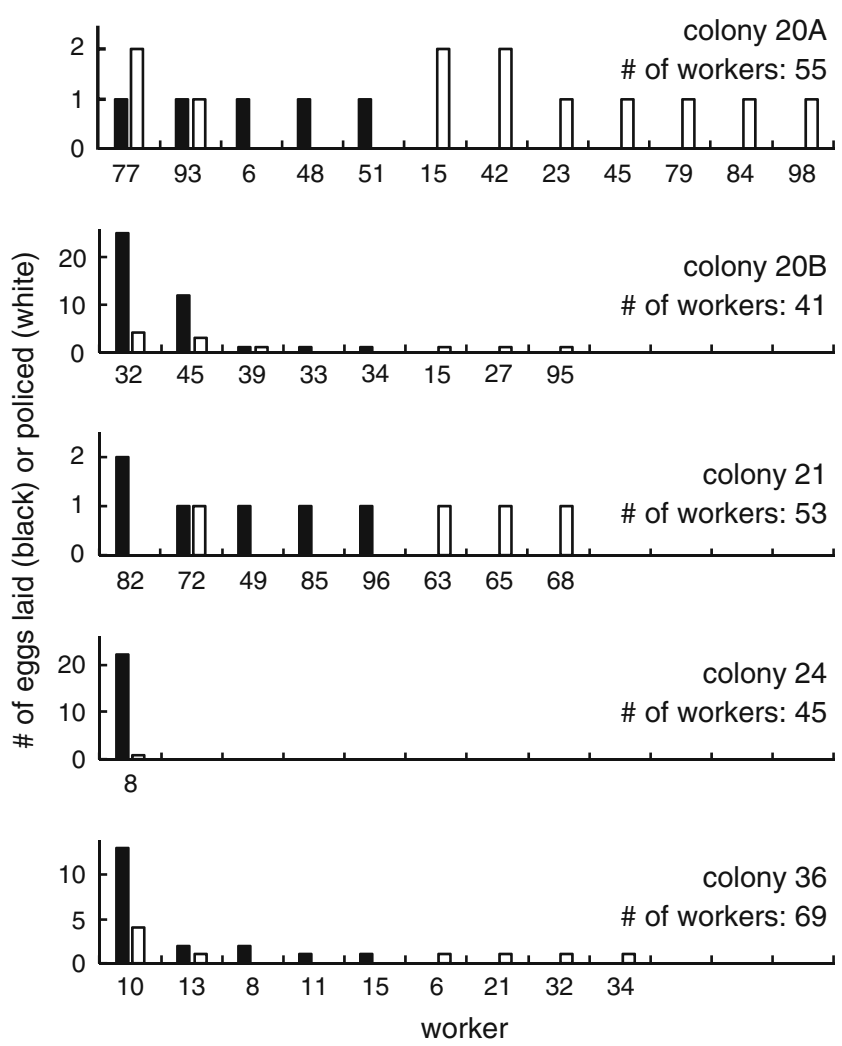

Fig. 2 Number of eggs laid (black) and policed (white) by individual workers in four colonies of Dolichovespula norwegica over the full length of our 24-h trials. The number of eggs policed include both worker-laid and queen-laid eggs

exact test, $p=0.78$, Table 2). Importantly, all groups of individuals that policed selectively removed worker-laid eggs (pooled data from all trials combined: Fisher exact test, queen: $p=1.8 \times 10^{-10}$, reproductive workers: $p=3.2 \times 10^{-6}$, non-reproductive workers: $p=0.003$; Table 2 ). There was no selective removal of worker-laid eggs for those cases where the identity of the policing individual could not be determined, which invariably involved eggs in peripheral cells that were obscured from view by nest envelope and which were later frequently destroyed.

\section{Specialisation in egg laying and policing}

On average, only four workers ( $8 \%$ of the total workforce) laid eggs in each colony (Table 3, Fig. 2). This is perfectly in line with earlier data demonstrating that $7.96 \%$ (16/201 workers) of the workers from another set of eight colonies of the same population had $>50 \%$ developed ovaries (Wenseleers and Ratnieks 2006b). Reproduction was approximately equally divided over all egg-laying workers in all colonies containing multiple egg-laying workers (all colonies except colony 24), with the effective number of egg-laying workers not being significantly different from the absolute number (paired $t$ test, $t=2.03 p=0.13$ ). The number of eggs eaten by individual workers, however, was significantly different from a random Poisson distribution (Table 3). This shows that worker policing was carried out by a specialised group of workers (Table 3, Fig. 2). Within this specialised group, the number of eggs eaten was approximately randomly distributed over the workers (Fig. 2). Taking into account non-sampling, we estimate that there were an average of 14 policing workers present in each colony (Table 3), which amounted to approximately one quarter of the work force, and that $66 \%$ of these (14/21, Fig. 2) were non-reproductive.

\section{Discussion}

In agreement with a previous study (Foster et al. 2001), our genetic data demonstrate that $D$. norwegica queens had a low effective mating frequency (1.2) and that, as a result, workers were significantly more related to other workers' sons than to the queen's sons. Hence, we had expected that
Table 3 Absolute and effective number of egg-laying workers, observed and estimated true number (correcting for non-sampling) of policing workers and statistical evidence for specialisation in policing (deviation from random sharing of egg eating across all workers, Kolmogorov-Smirnov test) in the four $D$. norwegica study colonies

\begin{tabular}{|c|c|c|c|c|c|}
\hline Colony & $\begin{array}{l}\text { Observed \# of } \\
\text { egg-laying workers (\%) }\end{array}$ & $\begin{array}{l}\text { Effective \# of } \\
\text { egg-laying workers }\end{array}$ & $\begin{array}{l}\text { Observed \# of policing } \\
\text { workers }(\%)\end{array}$ & $\begin{array}{l}\text { Estimated true \# of } \\
\text { policing workers }(\%)\end{array}$ & Specialisation in policing? \\
\hline $20 \mathrm{~A}^{\mathrm{a}}$ & $5(9 \%)$ & 5.0 & $9(16 \%)$ & $18(33 \%)$ & Yes, $\chi_{1}^{2}=4.53, p=0.03$ \\
\hline $20 \mathrm{~B}^{\mathrm{a}}$ & $5(12 \%)$ & 2.1 & $6(15 \%)$ & $9(22 \%)$ & Yes, $\chi_{3}{ }^{2}=149.77, p<0.00001$ \\
\hline 21 & $5(9 \%)$ & 4.5 & $4(8 \%)$ & $-{ }^{\mathrm{b}}$ & $-{ }^{\mathrm{b}}$ \\
\hline 24 & $1(2 \%)$ & 1.0 & $1(2 \%)$ & $-{ }^{\mathrm{b}}$ & $-{ }^{\mathrm{b}}$ \\
\hline $36^{\mathrm{c}}$ & $5(7 \%)$ & 2.0 & $6(9 \%)$ & $15(22 \%)$ & Yes, $\chi_{3}{ }^{2}=1,508.31, p<0.00001$ \\
\hline Average & $4(8 \%)$ & 2.9 & $5(10 \%)$ & $14(26 \%)$ & \\
\hline
\end{tabular}

\footnotetext{
${ }^{a}$ Data from this colony were collected during two separate series of 24-h observation trials in June (A) and July (B), respectively

${ }^{\mathrm{b}}$ Observed number of policing events $<5$, specialisation in policing could not be tested

${ }^{\mathrm{c}}$ Data from three 24-h trials pooled
} 
if worker policing occurred in this species, it would be selectively favoured by factors other than genetic relatedness (Ratnieks 1988; Foster and Ratnieks 2001b; Hartmann et al. 2003; Pirk et al. 2004; Nonacs 2006; Ohtsuki and Tsuji 2009) or that it would be partly driven by direct reproductive benefits, that is by "selfish" motives, and that some of the policing workers would lay eggs themselves (Wenseleers et al. 2005a; Ratnieks et al. 2006; Stroeymeyt et al. 2007; Brunner and Heinze 2009). In line with this prediction, we found that worker-laid eggs were killed by workers but that approximately two thirds of these were eaten by reproductive workers. This means that the evolution of worker policing in this species relied in part on direct reproductive benefits. In addition, approximately one third of the worker-laid eggs were removed by the queen. Hence, in this species, three kinds of policingqueen policing, worker policing and "selfish" worker policing-co-occur. In addition, since all these three forms of policing selectively targeted worker-laid eggs, they collectively resulted in a great reduction in the workers' share of colony reproduction. Approximately one quarter of all eggs were laid by workers but only $56 \%$ of these survived over the first $24 \mathrm{~h}$ of our trials versus $92 \%$ for queen-laid eggs. That not more of the worker-laid eggs were removed may be due to several factors: the queen is likely constrained in the efficiency of her policing efforts given there are many cells to check, the non-reproductive workers benefit to a certain extent from allowing the colony to rear workers' sons (nephews) over less related queen's sons and the reproductive workers have an incentive of not removing all worker-laid eggs, since that would impose too high a risk of killing their own eggs. The small percentage of queen-laid eggs that were eaten $(8 \%)$ might perhaps have been due to these eggs being unviable (in $V$. vulgaris and $V$. germanica $16-18 \%$ of the queen-laid eggs were shown to be unviable, Helanterä et al. 2006; Bonckaert et al. 2008) or due to recognitional mistakes.

Interestingly, although much of the worker policing in this species was partly carried out by egg-laying workers, the net effect of selfish worker policing was the same as for normal worker policing in that it increased the queen's share of the reproduction. This was because, when reproductive workers removed worker-laid eggs, they replaced it by one of their own in less than one third of all cases. This could have been because workers were limited in their egg-laying capacity or because egg-laying workers also carry out policing behaviour for the same reasons that non-reproductive workers policed worker-laid eggs in this species, such as to favour a more female-biased sex ratio (Foster and Ratnieks 2001b). In addition, even when the worker-laid eggs were replaced by another workers' egg, the replacement of worker-laid eggs likely resulted in significant delays in worker-laid eggs being reared into adulthood, which would also increase the queen's share of the reproduction.

Another important result of our study is that it revealed worker specialisation in policing (Table 3, Fig. 2). The division of labour in social Hymenoptera has been widely reported (Wilson 1971; Oster and Wilson 1978; Robinson 1992), but it has rarely been discussed for in the context of worker policing. Our results show that in colonies of the Norwegian wasp there was a clear, welldefined subgroup of workers that specialised in egg-eating behaviour, two thirds of which were non-reproductive workers. So far, specialisation in policing behaviour has only been documented in the ant Pachycondyla inversa (van Zweden et al. 2007).

Overall, our study demonstrates that patterns of policing in insect societies can be surprisingly complex and that all three forms of policing (queen policing, worker policing and "selfish" worker policing) can co-occur. This means that the different evolutionary explanations (relatedness, colony productivity and sex ratio) for the evolution of policing are not mutually exclusive but will have to be considered together to explain prevailing patterns of policing in insect societies. Most significantly, our study strongly supports "selfish policing" as an important kinselected mechanism that may facilitate the evolution of worker policing even in species where the workers are more closely related to sons of other workers than to sons of the queen. Counter-intuitively, we find that a behaviour that is driven by selfish competition over direct reproduction can contribute to the resolution of the conflict over male parentage in insect societies.

Acknowledgements We would like to thank the Institute for the Promotion of Innovation through Science and Technology in Flanders (IWT-Vlaanderen) and the Research Foundation Flanders (grant no. GNM-B5996-KAN2006) for funding. We are also very grateful to Kristel Vuerinckx and Tom Vanhove for help with video analysis and to Kristien Erven for help with the genotyping.

\section{References}

Bonckaert W, Vuerinckx K, Billen J, Hammond RL, Keller L, Wenseleers T (2008) Worker policing in the German wasp Vespula germanica. Behav Ecol 19:272-278

Boomsma JJ, Ratnieks FLW (1996) Paternity in eusocial Hymenoptera. Philos Trans R Soc Lond B Biol Sci 351:947-975

Bourke AFG (1988) Worker reproduction in the higher eusocial Hymenoptera. Q Rev Biol 63:291-311

Bourke AFG (1999) Colony size, social complexity and reproductive conflict in social insects. J Evol Biol 12:245-257

Bourke AFG (2005) Genetics, relatedness and social behaviour in insect societies. In: Fellowes MDE, Holloway GJ, Rolff J (eds) Insect evolutionary ecology. CABI, Wallingford, pp 1-30

Bourke AFG, Franks NR (1995) Social evolution in ants. Princeton University Press, Princeton 
Brunner E, Heinze E (2009) Worker dominance and policing in the ant Temnothorax unifasciatus. Insect Soc 56:397-404

Crozier RH, Pamilo P (1996) Evolution of social insect colonies. Sex allocation and kin selection. Oxford University Press, Oxford

D’Ettorre P, Heinze J, Ratnieks FLW (2004) Worker policing by eggeating in the ponerine ant Pachycondyla inversa. Proc R Soc Lond B Biol Sci 271:1427-1434

Daly D, Archer ME, Watts PC, Speed MP, Hughes MR, Barker FS, Jones J, Odgaard K, Kemp SJ (2002) Polymorphic microsatellite loci for eusocial wasps (Hymenoptera: Vespidae). Mol Ecol Notes 2:273-275

Endler A, Liebig J, Schmitt T, Parker JE, Jones GR, Schreier P, Hölldobler B (2004) Surface hydrocarbons of queen eggs regulate worker reproduction in a social insect. Proc Natl Acad Sci USA 101:2945-2950

Foster K, Ratnieks F (2000) Facultative worker policing in a wasp. Nature 407:692-693

Foster KR, Ratnieks FLW (2001a) Paternity, reproduction and conflict in vespine wasps: a model system for testing kin selection predictions. Behav Ecol Sociobiol 50:1-8

Foster KR, Ratnieks FLW (2001b) The effect of sex-allocation biasing on the evolution of worker policing in hymenopteran societies. Am Nat 158:615-624

Foster KR, Ratnieks FLW (2001c) Convergent evolution of worker policing by egg eating in the honeybee and common wasp. Proc R Soc Lond B 268:169-174

Foster KR, Ratnieks FLW, Gyllenstrand N, Thoren PA (2001) Colony kin structure and male production in Dolichovespula wasps. Mol Ecol 10:1003-1010

Foster KR, Gulliver J, Ratnieks FLW (2002) Worker policing in the European hornet Vespa crabro. Insect Soc 49:41-44

Halling LA, Oldroyd BP, Wattanachaiyingcharoen W, Barron AB, Nanork P, Wongsiri S (2001) Worker policing in the bee Apis florea. Behav Ecol Sociobiol 49:509-513

Hamilton WD (1964) The genetical evolution of social behaviour I \& II. J Theor Biol 7:1-52

Hammond RL, Keller L (2004) Conflict over male parentage in social insects. PLoS Biol 2:1-11

Hartmann A, Wantia J, Torres JA, Heinze J (2003) Worker policing without genetic conflicts in a clonal ant. Proc Natl Acad Sci U S A 100:12836-12840

Helanterä H, Tofilski A, Wenseleers T, Ratnieks FLW (2006) Worker policing in the common wasp Vespula vulgaris is not aimed at improving colony hygiene. Insect Soc 53:399-402

Hughes WOH, Oldroyd BP, Beekman M, Ratnieks FLW (2008) Ancestral monogamy shows kin selection is key to the evolution of eusociality. Science 320:1213-1216

Kellner K, Trindl A, Heinze J, D'Ettorre P (2007) Polygyny and polyandry in small ant societies. Mol Ecol 16:2363-2369

Lee ET, Wang JW (2003) Statistical methods for survival data analysis, 3rd edn. Wiley-Interscience, Hoboken

Liebig J, Monnin T, Turillazzi S (2005) Direct assessment of queen quality and lack of worker suppression in a paper wasp. Proc R Soc Lond B Biol Sci 272:1339-1344

Michener CD, Brothers DJ (1974) Were workers of eusocial Hymenoptera initially altruistic or oppressed. Proc Natl Acad Sci U S A 71:671-674

Monnin T, Peeters C (1997) Cannibalism of subordinates' eggs in the monogynous queenless ant Dinoponera quadriceps. Naturwissenschaften 84:499-502

Nielsen R, Tarpy DR, Reeve HK (2003) Estimating effective paternity number in social insects and the effective number of alleles in a population. Mol Ecol 12:3157-3164

Nonacs P (2006) Nepotism and brood reliability in the suppression of worker reproduction in the eusocial Hymenoptera. Biol Lett 2:577-579
Ohtsuki H, Tsuji K (2009) Adaptive reproduction schedule as a cause of worker policing in social Hymenoptera: a dynamic game analysis. Am Nat 173:747-758

Oldroyd BP, Halling LA, Good G, Wattanachaiyingcharoen W, Barron AB, Nanork P, Wongsiri S, Ratnieks FLW (2001) Worker policing and worker reproduction in Apis cerana. Behav Ecol Sociobiol 50:371

Oster GF, Wilson EO (1978) Caste and ecology in the social insects. Princeton University Press, Princeton

Pamilo P (1991) Evolution of colony characteristics in social insects 1. Sex allocation. Am Nat 137:83-107

Pirk CWW, Neumann P, Hepburn R, Moritz RFA, Tautz J (2004) Egg viability and worker policing in honey bees. Proc Natl Acad Sci U S A 101:8649-8651

Queller DC (2000) Relatedness and the fraternal major transitions. Phil Trans R Soc Lond B 355:1647-1655

Queller DC, Strassmann JE (1998) Kin selection and social insects. Bioscience 48:165-175

Ratnieks FLW (1988) Reproductive harmony via mutual policing by workers in eusocial Hymenoptera. Am Nat 132:217-236

Ratnieks FLW, Reeve HK (1992) Conflict in single-queen hymenopteran societies: the structure of conflict and processes that reduce conflict in advanced eusocial species. J Theor Biol 158:33-65

Ratnieks FLW, Visscher PK (1989) Worker policing in the honeybee. Nature 342:796-797

Ratnieks FLW, Foster KR, Wenseleers T (2006) Conflict resolution in insect societies. Annu Rev Entomol 51:581-608

Robinson GE (1992) Regulation of division of labor in insect societies. Annu Rev Entomol 37:637-665

Saigo T, Tsuchida K (2004) Queen and worker policing in monogynous and monandrous colonies of a primitively eusocial wasp. Proc R Soc Lond B Biol Sci (Suppl) 271:S509-S512

Starr CK (1984) Sperm competition, kinship, and sociality: a review of modern theory. In: Smith RL (ed) Sperm competition and the evolution of animal mating systems. Academic, Orlando, pp 427-464

Stroeymeyt N, Brunner E, Heinze J (2007) "Selfish worker policing" controls reproduction in a Temnothorax ant. Behav Ecol Sociobiol 61:1449-1457

Thorén PA, Paxton RJ, Estoup A (1995) Unusually high frequency of (CT)n and (GT)n microsatellite loci in a yellow jacket wasp, Vespula rufa (L.) (Hymenoptera: Vespidae). Insect Mol Biol 5:141-148

Trivers RL, Hare H (1976) Haplodiploidy and the evolution of the social insects. Science 191:249-263

van Zweden JS, Furst MA, Heinze J, D'Ettorre P (2007) Specialization in policing behaviour among workers in the ant Pachycondyla inversa. Proc R Soc B Biol Sci 274:1421-1428

Velthuis HHW, Araujo Alves D de, Imperatriz-Fonseca VL, Duchateau MJ (2002) Worker bees and the fate of their eggs. Proc Exp Appl Entomol NEV Amsterdam 13:97-102

Wang J (2004) Sibship reconstruction from genetic data with typing errors. Genetics 166:1963-1979

Wang J, Santure AW (2009) Parentage and sibship inference from multilocus genotype data under polygamy. Genetics 181:1579-1594

Wenseleers T, Ratnieks FLW (2006a) Comparative analysis of worker reproduction and policing in eusocial Hymenoptera supports relatedness theory. Am Nat 168:E163-E179

Wenseleers T, Ratnieks FLW (2006b) Enforced altruism in insect societies. Nature 444:50-50

Wenseleers T, Tofilski A, Ratnieks FLW (2005a) Queen and worker policing in the tree wasp Dolichovespula sylvestris. Behav Ecol Sociobiol 58:80-86

Wenseleers T, Badcock NS, Erven K, Tofilski A, Nascimento FS, Hart AG, Burke TA, Archer ME, Ratnieks FLW (2005b) A test of worker policing theory in an advanced eusocial wasp, Vespula rufa. Evolution 59:1306-1314

Wilson EO (1971) The insect societies. Harvard University Press, Cambridge 